\title{
Inscriptions in Old Norse Literature
}

\section{How Everything Started}

In medieval Scandinavia, writing is an asset which can only be earned with great sacrifice, but those able to pay the price can then grasp the written letter in a tangible way. We learn this lesson through the mythical genesis of runes in the eddic poem Hávamál (Sayings of the High One), in which Odin first brings runes into the world by sacrificing himself to himself:

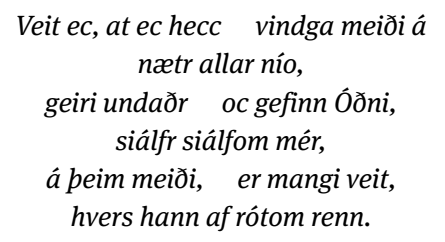

Við hleifi mic sældo né við hornigi,

nýsta ec niðr,

nam ec upp rúnar, œpandi nam, fell ec aptr paðan.

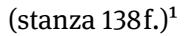

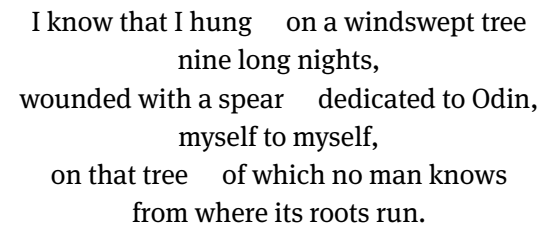
With no bread did they refresh me nor a drink from a horn, downwards I peered;

I took up the runes, screaming I took them, then I fell back from there.

If the text is taken literally, runes are, in fact, the opposite of an inscription, a carving that removes material to leaving the empty space as "script". Instead, these runes are both substantial and three-dimensional-otherwise they could not be "taken up". Even if they are not described as such in the stanza above, it is obvious that they are imagined as "staves", available as raw material for texts and writing. This myth of origin emphatically ascribes specific material qualities to writing in Scandinavia. Its acquisition is connected explicitly to corporality and magical practice: runes are acquired by Odin in the form of an initiation rite; they are regarded as "divine knowledge", their origin is imbued with transcendental qualities.

The following chapter will explore these factors further by investigating how literary texts imagine both the material qualities of writing and the practices that contextualise how script is used. It will consider objects turned into artefacts by the addition

1 All eddic quotes refer to the edition by Neckel/Kuhn 1962. The translation used is by Larrington 2014. Translations of other Old Norse texts are my own, unless a translation is listed in the bibliography.

This article has been translated by Stefan Drechsler.

๑ Open Access. (C) 2019 Katja Schulz, published by De Gruyter. (c) BY-NC-ND This work is licensed under the Creative Commons Attribution-NonCommercial-NoDerivatives 4.0 License. 
of script, as well as text-bearing objects that were artefacts before they were embellished with writing. Finally, it will discuss both the human actors who use script and the topological contexts of inscriptions in Old Norse literature.

\section{Script and the Transmission of Text in the North}

This volume is dedicated to script beyond the standards of writing with pen and ink on parchment. But is it possible to define a "standard of writing" for medieval northern Europe? In contrast to the Continent, most parts of Scandinavia possessed not one but two writing systems: runic writing and Latin script.

Latin writing was brought to the North with Christianity, predominantly from Anglo-Saxon areas: first in manuscripts, which were taken to Norway and Iceland initially as booty or items of trade from Viking raids, and then in the course of the Christianisation beginning in the tenth century. It cannot be articulated with certainty when exactly writing built upon Latin letters commenced in the North. It may be surmised that, with the settlement of Iceland around 900, some settlers from England may have taken books with them. Furthermore, an intense cultural exchange between Norway and England which brought both books and the literacy of clerics to the north may have contributed to the arrival of Latin writing in the tenth century. The oldest evidence of Latin script in Scandinavia are fragments of liturgical books (c. 950), while the oldest vernacular fragments (written on calfskin) have been dated to the second half of the twelfth century. In comparison with Europe, northern countries are rather late in introducing the Latin alphabet, but comparatively early in implementing vernacular writing: the oldest preserved vernacular prose text written in a Scandinavian language is the Íslendingabók (Book of the Icelanders) by Ari Porgilsson inn fróði, which was composed around $1125 .^{2}$ A further cultural difference between Iceland and the Continent concerns the dissemination of literacy. While the clergy monopolised writing on the Continent, Iceland was ruled by an oligarchy of magnate farmers who were also literate. Written culture, therefore, more often followed the will of powerful farmers rather than the interests of the Church. ${ }^{3}$

Prior to the rise of Latin literacy, the north made use of a runic alphabet; the oldest sources-dating from c.200-are from the area of modern Denmark. Materials used for such writing were mainly stone, wood and metal, but bones were also common. In this regard, runic script was created to be inscribed; intended to be written into the material rather than onto it. With their angular shapes, runes are suitable to be

2 Already in 1117, however, a decision was made to record laws in Icelandic.

3 An overview of the origins of Old Norse literature, with particular regard to media and other aspects of textuality, has been presented by Glauser 2006. 
carved on solid material-against the grain of wood, for instance. ${ }^{4}$ Early runic inscriptions in particular are often found on artefacts with pragmatic functions, such as helmets, drinking horns or pieces of jewellery. From the middle of the eleventh century onwards, the number of preserved wooden or bone staves whose sole purpose was to carry an inscription increased dramatically. Their comparative scarcity in earlier times, however, may be due to the simple fact that wood or bone decays faster than stone or metal. At the same time, it could indicate a change in the function of writing which might have accompanied the growing prominence of Latin writing culture. ${ }^{5}$

Since the first millennium, then, two systems of writing were available in Scandinavia. For one, writing was a form of carving or engraving into material; for the other, writing was a form of application of one medium to another. This functional differentiation of scripts-“in-scription" and "on-scription", if you will-has several significant implications for the investigation of extraordinary forms of the writing in the Middle Ages more generally. First, a search for narrated inscriptions in Old Norse literature will privilege primarily narratives about runic inscriptions, since runes are the form of script most likely to be engraved or carved. Concomitantly, it will also foreground those materials and mediums related to such inscription practices such as wood or bone. At the same time, this choice also compels the social context: Latin script requires-at least in the North-parchment and ink, which was only available in certain milieus, while runic script only needs a piece of wood and a knife, both available to virtually everybody. In this respect, Scandinavian literature complicates a basic assumption for this volume that inscriptionality is an extraordinary-which is to say exceptional-form of writing. Especially in situations that urgently call for a written message, wooden sticks and a knife were the most readily available resources for writing. This is reflected in a passage of Hákonar saga Hákonarsonar, a Kings' saga composed by Sturla Pórðarson in 1264f.: a messenger approaches the king to bring him a "rune stick", a rúnakefli, which carries news of the death of his rival. The king reacts by having those around him begin "preparing a letter". ${ }^{6}$ This example highlights the heterogeneity of writing practices in Scandinavia, where inscription is the more common practice, and draws attention to the social significance, in this case related to class or rank, attributed to these forms of writing.

\footnotetext{
4 Basic information on runes and runic inscriptions are offered in Düwel 2001.

5 Cf. Seim 2004, 121.

6 Pa er Hakon konvngr reið vpp til Alreksstaða einn sunnodag or Biorgyn sem vandi hans var til. kom a mót honom einn hlavpanndi maðr akafliga af Ribbvngom. hann hafði rúnakefli $i$ hendi pat sem einn Ribbvngr sendi konvnginom ok sagði sva at Sigvrðr Ribbvnga konvngr var andaðr. [...] Konvngr let pegar gera bref austr til Knvtz frænda sins ok baup honom goða kosti sem fyrr (Codex Frisianus, ch. 150, 464; the manuscript has been dated to the first quarter of the fourteenth century).
} 


\section{Functions of Inscriptions}

The First Grammatical Treatise, composed around the middle of the twelfth century by an unknown writer, offers insight into the primary intended function of Latin writing in Scandinavia:

I have composed an alphabet for us Icelanders as well, in order that it might be made easier to write and read, as is now customary in this country as well, the laws, the genealogies, the sacred writings, and also that historical lore which Ari Thorgilsson has recorded in his books with such understanding wit. ${ }^{7}$ I have used all the Latin letters that seemed to fit our language well and could retain their proper sound, as well as some other letters that seemed needful to me, while those were put aside that did not suit the sounds of our language; ${ }^{8}$

These "different letters" were taken from the vernacular runic alphabet, of course.

Thus, if the Icelandic grammarian is to be trusted (and the earliest testimonies corroborate his case), the introduction of Latin script was initially intended to write down law texts, historiographic, and religious writings, offering the possibility to preserve larger texts. By contrast-due to the greater efforts required to write themrunic inscriptions tend to be rather short. Where reasonably reliable interpretations are available, these inscriptions often consist of names, information on an artefact's owner or craftsman, magic inscriptions on amulets, commemorations, and inscriptions which express the ability to write in runes. With the advent of the Viking Age in the late eighth century, the number of rune stones increases, most of which carry inscriptions of commemoration. Often formulaic supplements are added, like information about who carved the runes, formulae of protection, magical formulae, invocations to the god Thor, or Christian blessings. By the twelfth century wooden staves become a medium for everyday communication, as evidenced by an archaeological discovery following a fire in the Norwegian city of Bergen. These runesticks-dating from the twelfth up into the fifteenth centuries-contain a large variety of messages from daily life: accounts, business letters, goods labels, love letters, satirical poems, Christian and magical formula ranging from an ardent wish to the rudest obscenity. ${ }^{9}$ The choice of either Latin or runic writing thus was dependent on the length of text, on the available medium, and, relatedly, the social rank of the writer.

7 This refers to the aforementioned Íslendingabók.

8 til pess at hogra verði at ríta ok lesa, sem nú tíðisk ok á pessu landi, bæði log og áttvísi eða pýðingar helgar, eða svá bau in spakligu froði, er Ari Pórgilsson hefir á bœekr sett af skynsamligu viti, pá hefi ek ok ritit oss íslendingum stafróf, bæði látínustǫum ọllum peim er mér pótti gegna til várs máls vel, svá at rétt ræðir mætti verða, ok peim ǫðrum, er mér pótti í purfa at vera, en ór váru teknir peir, er eigi gegna atkvæðum várrar tungu. (First Grammatical Treatise, 12f.).

9 Cf. Düwel 2001, 12, 95-97, 153-160. 


\section{Old Norse Literature}

Shortly after the introduction of Latin script, writing culture expanded beyond laws, historiographic and religious texts to include other kinds of literature as well. Translations and adaptations of continental courtly literature became popular in the North, along with medieval ballads. Additionally, an independent literature emerged in Iceland and Norway which had no immediate counterpart among other medieval literary genres. It is characterised by three groups of texts: the sagas, eddic, and skaldic poetry. Sagas are stories in prose, often with interspersed stanzas. In most instances, they originated anonymously and were transmitted orally first and in manuscripts from the late twelfth century onwards. Depending on the time, place and protagonist of the story, sagas are classified into a number of subgroups: Kings' sagas, Family sagas, Legendary sagas, Bishops' sagas and Contemporary sagas address Norwegian and Icelandic history, while Saints' and Chivalric sagas are sometimes translations of hagiographic or Old French courtly literature, but sometimes also original literature composed in western Scandinavia. Due to their realistic style of narration, the Family sagas in particular were uncritically seen as historical or anthropological sources up until the twentieth century.

The name Edda applies to two thematically related but stylistically dissimilar Icelandic groups of texts dated to the thirteenth century: the Poetic Edda and the Snorra Edda. The eddic poems-bequeathed in a main manuscript from c. 1275 named Codex Regius (GKS 2365 4to)-are anonymous, alliterative poems dealing with Nordic gods and heroes. Some of these poems are quoted and in parts re-narrated in the so-called Snorra Edda, a poetological compendium consisting of three parts, which was composed by Snorri Sturluson (1179-1249) in c.1220. The first section, Gylfaginning (The Deception of Gylfi), recounts the mythological history of the north in prose form as it is a requirement for the correct usage of the poetical language, the so-called kennings in particular (metaphor-like, poetical circumlocutions). These kennings are gathered and described in the second part, Skáldskaparmál (Language of Poetry), while the third part, Háttatal (List of Metres), is an annotated didactic poem of all known skaldic metres in 102 stanzas.

Skaldic poetry, the third genuine contribution from western Scandinavia to world literature, is a highly artificial alliterating form of poetry, which was already becoming obscure and subject to misunderstandings during Snorri's lifetime. This is mainly due to the kennings-many of which became unintelligible-as well as due to the poems' highly complex syntax and variety of verse metres. Unlike the other two major genres, skaldic poems were composed by poets-skalds-often identified by name.

For an indeterminate amount of time, all three of these "classical" Old Norse genres were transmitted orally both before and after they were written down-with Latin script. As a consequence, the meta-textual information transmitted in these texts is information about the cultural "other" in regard to script: it is a commentary in Latin script on runic inscriptionality. 


\section{Terminology of Inscriptionality}

The vernacular verbs used for writing indicate with varying degree of certainty if the text is meant to be an inscription or meant to be written on a surface (parchment) with Latin letters. Old Norse rísta or rista, meaning basically "to cut" or "to carve", most likely refers to inscribing something with runes. Rita, on the other hand, which also means "to carve", is the main term used for book writing and in translated literature often corresponds to the Latin scribere. Etymologically related to scribere is the Old Norse verb skrifa, which has a broad range of meanings such as "to describe", "to draw", "to paint”, or "to write”; often skrífa also refers to "drawn stories”. A similar semantic uncertainty is characteristic of other verbs, such as marka "to draw, represent, identify, label”, or penta "to paint, to embellish with drawings." Often only the context clarifies whether these verbs refer to a visual or a scriptural presentation. ${ }^{10}$

In Alexanders saga, ${ }^{11}$ all of these verbs are used to describe the tombstone of the wife of Darius:

Eigi voro par áscrivoð eða scoren at eins nofn oc verk Grickia konunga helldr var oc par til teket er heimrenn var scapaðr. (62)

Not only were there names and deeds of Greek kings depicted or engraved; rather, it began with the creation of the world.

In addition to skrifa (here contracted with the preposition a "on (to)"), the verb skera "to cut", "to engrave", and "to carve" emphasises technical skills and materiality. In the description of the stone that follows, it is for the most part impossible to determine whether the verb used most frequently, marka, refers to pictorial or written depiction. On the other hand, skrifa in this passage stands in most cases for "to write", as it is supplemented in several cases with the accusative object nofn "name" and thus refers to language. As a general rule, other words are required to indicate whether a verb refers to inscription. An example is penta, which is sometimes complemented by "with golden letters" (með gullstofum) or similar descriptions.

In the context of runic inscriptions, other verbs underline praxeological aspects. The verb rjóða ("to redden"), for example, is used several times in magical contexts where previously carved runes are reddened with blood. Furthermore, fá ("to colour") is sometimes used in relation to runes. Moreover, written runes are read and interpreted (lesa, kunna, ráða) or sometimes blessed (vígja). ${ }^{12}$

10 For references to the individual termini, see the Dictionary of Old Norse Prose of The Arnamagnaean Commission at the University of Copenhagen: http://onp.ku.dk (last accessed: 30.05.2019). 11 Alexanders saga is an Old Norse translation of Alexandreis of Gualterus de Castiglione (c.1135 until post 1184), which was translated and commented by the Icelandic abbot Brandr Jónsson in c. 1260. 12 For this see Ebel 1964. 
When considering text-bearing objects, there are, on the one hand, artefacts with a pragmatic function that have been embellished (such as helmets, weapon, or jewellery) and, on the other, objects whose sole purpose is to bear a text. The most common term for the latter is kefli ("piece of wood"), sometimes also in the compound rúnakefli ("runestick"). Occasionally, a spjald (pl. spjold, "panel”, "plate”) is mentioned, which in translated texts replaces the Latin tabulum / tabula. An example is steinspjald ("stone plate") for the Tablets of Moses. In addition, wax tables (vaxspjold) are mentioned at times, predominantly in religious texts from the fourteenth century onwards. For the script itself, the word rúnar (fem. pl.) is used, which has a broad range of meanings including "Latin letters", "runes", as well as "wisdom", "learning", "literature", and "magical signs". Stafr ("stave") is used often in relation to letters and corresponds to Latin littera. For example, the Latin Littera est pars minima vocis compositae is rendered in the Third Grammatical Treatise (from the early fourteenth century) as Stafr er hinn minzti lvtr raddar saman sættrar, sæm rita ma. ${ }^{13}$ Often compounds such as bók- or rúnarstafr, stafróf and so forth are used, most frequently in translation literature or as terms for reading, for written knowledge, or for foreign languages such as latino stafi / girzkum stöfum / ebraiskum stöfum (with Latin/Greek/ Hebrew letters).

\section{Actors}

As the introductory paragraph has already demonstrated, script is conceived as divine in the medieval Scandinavian imagination, received and transmitted by Odin. The highest god in Norse mythology is, among many other aspects, also the god of poetry and runes. Hávamál also mentions how Odin steals the mead of poetry, a potion which transforms everyone who drinks from it into a poet, from the giants. According to the seventh chapter of Ynglinga saga-the first section of Heimskringla ${ }^{14}$-Odin uses runes to convey his magical skills: "All these skills he taught along with runes and those songs that are called galdrar (magic spells)" (Allar pessar ípróttir kendi hann með rúnum ok ljóðum peim, er galdrar heita, $7 \mathrm{f}$.). The mythological sources confirm that wisdom about runes is privileged and can only be passed on to selected receivers. The eddic poem Sigrdrifumál (Sayings of Sigrdrífa) relays-for instance-how the valkyrie Sigrdrifa (equated with Brynhildr in some texts) conveys knowledge about runic magic (stanzas 6-19) and advice for appropriate behaviour (22-37) to Sigurd, probably on behalf of Odin. Part of the instructions on runes in Sigrdrífumál is a report

13 Den tredje og fjærde grammatiske afhandling 1884, 37.

14 Heimskringla (literally "the Earth's circle") is a history about the Norwegian kings composed by Snorri Sturluson around 1230. In the first part, Ynglinga saga, Nordic gods are euhemerised and depicted as magically gifted humans. 
on their mythic origin, which is revealed to Sigurd. ${ }^{15}$ Sigurd proves himself worthy of the instruction by demonstrating his fearlessness with his ride through the ring of fire encircling the valkyrie.

In another eddic poem-Rigspula - the knowledge of runes is a privilege of kings (stanzas 43, 45) and conveyed by the god Rígr ${ }^{16}$ (stanza 36). According to Rígspula 45, a young ruler is legitimated through the use of runes once he has demonstrated that he is able to apply them better than his father:

Hann við Ríg iarl rúnar deildi, brogðom beitti oc betr kunni; pá ǫ̆laðiz oc pá eiga gat Rígr at heita, rúnar kunna.
He contended in rune-wisdom with Lord Rig, he played more tricks, knew more than he did; then he gained and got the right to be called Rig and to deploy runes.

Knowledge of runes is in this respect equal to the ability to read books. This is mentioned in a skaldic stanza of the Old Norse earl Rognvaldr from the twelfth century. Rognvaldr boasts of himself:

\author{
"Tafl emk orr at efla; \\ ípróttir kannk niu; \\ týnik trauðla rúnum; \\ tíðs mér bók ok smíðir. \\ Skríða kannk á skíðum; \\ skýtk ok roek, svát nýtir; \\ hvártveggja kannk hyggja: \\ harpslôtt ok bragpôttu". \\ (576f.)
}

\author{
"I am quick at playing board games; \\ I have nine skills; \\ I forget runes slowly; \\ the book is a preoccupation with me and also \\ craftsmanship. \\ I am able to glide on skis; \\ I shoot and I row so that it makes a difference; \\ I am able to understand both: \\ harp-playing and poems”.
}

In praise of the Indian prince Liforinus, Nitíða saga, an Icelandic romance from c. 1400 , enumerates, among many other virtues, that Liforinus is able "to read runes and books" (runar og bækur at lesa, 9).

Similar to Odin as the head of mythic society and the king as the head of a king dom, in the Family sagas magnate farmers and chieftains are depicted as leaders of society. In the whole corpus of Family sagas, no one is more closely associated with the use of runic script than the tenth-century magnate farmer and skald Egill Skalla-Grímsson. The thirteenth-century Egils saga Skalla-Grimssonar depicts its eponymous protagonist as an Odinic hero who is linked to the god through his abilities as poet and skills in runes. In Egils saga, the use of runes and inscriptions is described in a realistic, mundane setting. The saga elucidates that the correct use of runes is reserved for qualified rune-carvers only. In chapter 72, Egill cures a sick girl who was accidentally cursed by a farmer boy with a love charm carved on a fish bone. Later on, in chapter 76 , the narrator explains:

15 See the commentary by von See et al. 2006, vol. 5, 572-592.

16 Some consider Rígr as Heimdallr, some as Odin; cf. von See et al. 2000, vol. 3, 486f., 508f., 514-516. 
pá póttisk hann rísta henni manrúnar, en hann kunni pat eigi, ok hafði hann pat ristit henni, er hon fekk meinsemi af. (238)

he thought he would carve love-runes for her, but he had not the skill, and what he had carved caused her illness.

This demonstrates that the combination of runes and the material object they are inscribed on is more powerful than the intention of the carver: it is not important what he wants and what spells he may pronounce while carving; rather, the effect lies in the staves themselves as they are carved. Similar to the previously mentioned mythological poems, the saga assumes that exact knowledge of runes and their use is required-qualities for which Egill is famous, but which cannot be obtained by an infatuated young rascal whose name is not even mentioned in the saga. The carving of runes is a special skill and the uninitiated should not dabble in them. This is pointedly underlined by Egill in a skaldic stanza which follows this episode:

\begin{abstract}
Skalat maðr rúnar rísta, nema ráda vel kunni, bat verðr morgum manni, es of myrkvan staf villisk; sák á telgðu talkni tíu launstafi ristna, pat hefr lauka lindi langs ofrtrega fengit.
\end{abstract} (230)

\author{
No man should carve runes \\ unless he can read them well; \\ many a man goes astray \\ around those dark letters. \\ On the whalebone I saw \\ Ten secret letters carved, \\ from them the linden tree [= woman] \\ took her long harm.
}

When he detects the incompetently carved runes on the fish bone, Egill scrapes them off and burns the scraped material; then he carves new runes into the bone. He orders a change of the bed linen in which the fish bone and the sick girl had lain, and has the old sheets aired out. Slightly later, in chapter 76, the incident is referred to again and explained. Such emphasis on an otherwise incidental event suggests the marked importance of Egill being a particularly skilled rune carver. Several other examples of his carvings will be discussed further below.

The main focus of this chapter so far has been the socially and intellectually privileged users of runes. There are, however, also a number of examples in which rune-magic is practiced by people of lower status, such as the messenger of the gods Skírnir (in the eddic poem Skírmismál) or an old foster mother in Grettis saga. In factin all the genres described above-it is quite common that women are knowledgeable of runes. ${ }^{17}$ Sometimes their skills are made explicit, as in the eddic poem Atlamál (stanza 11 and 12) and in a prosaic paraphrase of the same episode in Volsunga saga (ch. 35 [33]). In this poem, Kostbera-the wife of Họgni-not only understands that a

17 For this, see also Dillmann 2003, 544. 
runic message has been compromised, she is also able to identify the original message underneath. Kostbera discerns that Atli, Guðrún's husband, has had Guðrún's original message warning her brothers of treachery distorted into an invitation, and so warns her husband: ${ }^{18}$

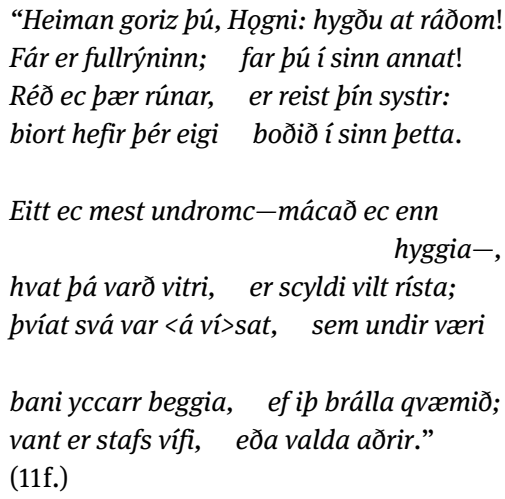

"Heiman goriz pú, Hogni: hygðu at rádom! Fár er fullrýninn; far pú í sinn annat! Réd ec pær rúnar, er reist pín systir: biort hefir pér eigi boðið ísinn petta.
Eitt ec mest undromc-mácað ec enn
hvat pá varð vitri, $\quad$ er scyldi vilt rísta; pvíat svá var <á ví>sat, sem undir væri
bani yccarr beggia, ef ip brálla qvæmið; (11f.)

\begin{abstract}
"You intend to leave home, Hogni, listen to advice! Few are very learned in runes-go some other time! I interpreted the runes which your sister cut: the radiant lady hasn't summoned you this time.

I'm greatly surprised by one thing-I still can't make it outwhy the clever woman should carve so awry; for they seemed to indicate an underlying meaning: the death of both of you if you hastened there now; the lady's missed out a letter or else others have caused this."
\end{abstract}

Thus, even as there are some social differences in the use of runic inscriptions and Latin script-as exemplified by messenger's runestick and king's letter (likely on parchment) in Hákonar saga Hákonarsonar-, in general it would appear that the use of writing in the primary Old Norse sources is not considered as restricted to a particular age, gender, or social rank. Rather it is a matter of initiation.

\section{Practices}

The actions of Egill against the erroneous rune magic of the uninitiated farmer boy have shown that the use of script is related to specific practices. It is indeed remarkable that a number of narrated inscriptions with a magical purpose explicitly mention the process of carving and other practices. An unusually vivid example is found in Grettis saga, a Family saga from the fourteenth century, which recounts the Icelandic Viking-Age through the biographical story of Grettir Ásmundarson "the Strong”, a skald who presumably lived in the eleventh century. The saga's concluding lines commemorate Grettir as the strongest man of his time and the most skilled

18 Jürg Glauser has proposed that this motif testifies to the change of media from non-scriptural, non-verbal to verbal signs: in the older Atlakviða, Guðrún sends a ring wrapped in a wolf's hair as a warning to her brothers while in the younger Atlamál, the ring is replaced by the runic message. The prosaic re-narration in Völsunga saga combines the two codes and represents the written code as potentially deceptive (Glauser 2006, 16f.). 
at banishing revenants. His enemy can only overcome Grettir with the help of his foster-mother púríor. She

was very old and not able to do much, so people thought. She had been very skilled in magic and had great knowledge of sorcery when she was young and people were heathen. Now it looked as though she must have forgotten it all. But though Christianity ruled in the land, there were yet many sparks of heathendom remaining. ${ }^{19}$

This episode reflects a general tendency in all the genres discussed above to associate magical runic usage with heathen customs. The scene describes in great detail how púríor performs her task (ch. 79):

er hon kom til strandar, haltraði hon fram með sænum, svá sem henni væri vísat til. Par lá fyrir henni rótartré svá mikit sem axlbyrðr. Hon leit á tréit ok bað pá snúa fyrir sér; pat var sem sviðit ok gniðat oðrum megin. Hon lét telgja á lítinn flatveg, par gniðat var; síðan tók hon kníf sinn ok reist rúnar á rótinni ok rauð í blóði sínu ok kvað yfir galdra. Hon gekk ofug andsœlis um tréit ok hafði par yfir morg rọmm ummæli. Eptir pat lætr hon hrinda trénu á sjá ok mælti svá fyrir, at bat skyldi reka út til Drangeyjar, ok verði Gretti allt mein at. (249f.)

when she got to the shore, she limped along by the water as if she was being guided. There lay before her a log of wood with its root as big as one could carry on one's shoulder. She looked at the log and told them to turn it over for her. It looked as though it had been scorched and rubbed on one side. She had a little flat bit carved where it had been rubbed. Then she took her knife and cut runes on the root and reddened them with her blood and recited spells over them. She walked backwards withershins round the log and spoke over it many powerful formulas. After that she had the log pushed into the sea and made this pronouncement that it was to drift out to Drangey and be a source of every evil to Grettir.

The spell proves to be effective: while Grettir tries to cut the driftwood into firewood, he harms himself and the wound eventually causes his death.

An equally detailed episode occurs in chapter 57 of Egils saga, wherein Egill erects a niðstǫng (mocking pole) and carves curses into it; this episode will be discussed further below. This kind of magical inscription is not only found in fictional texts, but also in the medical literature. In order to fight jaundice or anaemia, for example, one should carve prayer formulae into wooden sticks and burn them in an invocation of St Mary (AM 461 12mo, a parchment manuscript dated to the sixteenth century). ${ }^{20}$ Usually, as evidenced in these examples, spoken components accompany such practices. In other words, one must recite magic spells or invoke gods or saints while carving. In the eddic poem Sigrdrifumál the heroine suggests the incision of victory-runes

19 Fóstru átti Porbjorn ongull, er Puríðr hét; hon var mjǫ gǫmul ok til lítils foer, at pví er monnum pótti. Hon hafði verit fjolkunnig mjok ok margkunnig mjok, pá er hon var ung ok menn váru heiðnir; nú pótti sem hon myndi ollu týnt hafa. En pó at kristni væri á landinu, pá váru pó margir gneistir heiðninnar eptir (ch. 78, 245).

20 Alfræði íslenzk, vol. 3, 109. 
on a sword-hilt, on its blade-guards and on the handle, all while invoking the god Tyr twice (Sigrdrífumál, 6).

\section{Material Dimension and Presence}

The introduction to this volume makes clear, the materiality of script and medium is crucial for the study of narrated inscriptions. One can distinguish between script on a medium which is intended primarily for this purpose-such as runic wooden sticks, a wax tablet, or parchment-and script on an object not generally used for writing. According to Sigrdrifumál, the whole world can be written upon. When the Valkyrie clarifies the use of runes and the places on which they shall be carved, she includes not only the sword mentioned above, but also a drinking-horn, the back of the hand, a nail, the palms, the prow, the rudder, the oar, the bark, the tree of the wood whose branches bend east, the shield which stands before the sun, the ear and the hoof of horses, the teeth of Odin's horse, the bear's paw and the tongue of Bragi (the god of poetry), the wolf's claw and the eagle's beak, bloody wings and at the end of a bridge, on a glass and on gold and on men's amulets, in wine and on wort and on a favourite seat. These are only some of the media mentioned in stanzas 6 to 19 of the poem as potential bearers of runes.

Often the object bearing the runic text has a sympathetic relationship to the intended effect of its inscription. Victory runes on a sword help to gain victory, helping-runes on the palms of hands of a midwife help with an easier childbirth, and sea runes on the stem and oar of a ship facilitate a smoother journey on a rough sea. In these instances the presence of script plays an obvious role: script unfolds its (magical) effect at the place where it is affixed. The penultimate stanza of the rune section, Sigrdrifumál 18, shows that magic runes are imagined as material. The poem specifies that all runes whose effects and places were listed previously
Allar vóro af scafnar pær er vóro á ristnar, oc hverfðar við inn helga mioð oc sendar á víða vega;
pær ro meðásom, pær ro meðálfom, sumar með vísom vǫnom, sumar hafa mennzcir menn.
were shaved off, those which were carved on, and stirred into the sacred mead and sent on wandering ways; they are among the Æsir, they are among the elves, some are with the wise Vanir, some with humankind.

The knowledge of runes and their impact is materially scraped off and mingled into the mead; in this way it becomes substantially concrete, real, and present and can literally be swallowed as spiritual nourishment. ${ }^{21}$

21 On the conception of presence in medieval cultures, and its usage on script and script-bearing objects, see Hornbacher/Frese/Willer 2015. 
As we have seen in Egill's runic countermagic, the material aspect of script is crucial: the runes are physically removed from the textual medium and the scraped material is burned. That the magical effect of runes can be reversed is also evident in Skírnismál, where Freyr's "postillon d'amour" Skírnir woos the giantess Gerðr for the god. To compel the unwilling giantess, Skírnir makes use of a curse which obliterates all the joys of life (stanzas 25-36) and finishes with a rune spell:22

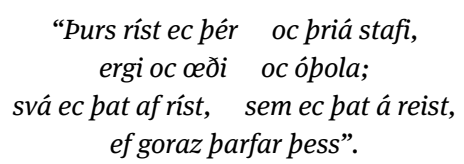

(stanza 36)

\footnotetext{
“'purs' I carve for you and three runes: Lewdness and frenzy and unbearable desire; I can carve that off, as I carved that on, if there is need of this.”
}

The curse is "activated" with the carving of three Purs-runes into a "taming wand" (tamsvondr), which is mentioned at the beginning of the curse. Skirnir seems to start carving the runes while he speaks, since he declares in stanza 36 that he will undo the spell "if there is need of this"; in other words if Gerðr yields, which she subsequently does in stanza 37. Here again, the detrimental effect of runes is eliminated when they are abrased. The effect, therefore, is embedded in the connection between wood and script. The signs form a unity with the material, transforming the nature of both.

The same may be said for a drinking horn into which Egill carves runes in chapter 44 to save himself from a poisoned drink. After carving, he smears these runes with his own blood. He describes his action with a stanza:

\author{
Rístum rún á horni, \\ rjóðum spjǫll i dreyra, \\ pau velk orð til eyrna \\ óðs dýrs viðar róta; \\ drekkum veig sem viljum, \\ vel glýjaðra pýja; \\ vitum, hvé oss of eiri \\ ol, pats Bárøðr signdi.
} (109)

\author{
I carve runes on this horn, \\ redden words with my blood, \\ I choose words for the trees \\ of the wild beast's ear-roots [= horns]; \\ drink as we wish this mead \\ brought by merry servants, \\ let us find out how we fare \\ from the ale that Bard blessed.
}

The horn then breaks and the drink runs to the ground.

Through the carving of runes and their intensification through blood, the horn undergoes an essential change: it becomes an actor that provides information about the harmful or innocuous nature of the drink which it contains. Here the immediate presence of script determines its impact. Runes carved into horns can also affect the properties of the drink, as exemplified in the eddic Guðrúnarkviða onnur (Second

22 On the stanzas featuring the curses, see von See et al. 1997, vol. 2, 106-137. A quite similar application is also known by Odin, for example, who puts an insanity spell on the giantess Rindr to beget an avenger for his son Balder with her (Saxo Grammaticus, Gesta Danorum 2015, 164f. [lib. III iv.4]). 
Poem of Gudrun): Gudrun is given a drink by her mother which causes her to forget Sigurd, her murdered first husband. "That drink was augmented with fateful power, with the cool sea, with sacrificial blood", and "In the drinking horn were all kinds of runes, / cut and red-coloured [...] / a long heather-fish, an uncut corn-ear / of the Haddings land, the entrail of beasts". ${ }^{23}$ The material presence of script is also a condition for its efficacy in Magus saga jarls, an original Chivalric saga from the fourteenth century. This saga mentions (37f.) that the carving of runes on the shield of Rognvaldr causes each bearer of that shield to take on the appearance of its original owner. Rognvaldr arranges that the shield falls into the hands of one of his enemies, which results in several deaths: everyone who assumes that he has killed an alleged Rognvaldr takes up his shield and thus turns into the next victim.

\section{Locomobile and Locostatic Inscriptions}

Most of the examples of inscriptions discussed above are locomobile, able to take effect at different places depending on where they are carried to (shield, love charm on fish bone, log of wood with curse spell). The concept that script can serve as an efficacious intermediary between two persons also explains the frequent mention of runic wooden sticks in magical contexts. Moreover, such an application of script is not restricted to runic letters. For help with a difficult birth, an Icelandic encyclopaedic manuscript from the sixteenth century (AM 431, 12mo) explains that the Holy Book should be bound to the right thigh of the mother, together with Latin supplications written on a piece of wood or a small parchment. ${ }^{24}$

A rune stick-rúnarkefli-is perhaps the most commonly referenced medium for inscription in Old Norse literature; it is the notepad of the Nordic Middle Ages, carrying messages from one place to another (as we have seen in Hákonar saga Hákonarsonar), able to record the survival of a hero or preserve a quickly sketched stanza (Grettis saga, ch. 66). It is suitable as a tool of memory to withstand the test of time, but also for the transportation of texts of all kind. The findings in Bergen testify to the widespread utilisation of runic wooden sticks in the Middle Ages.

Inscriptions in stone, on the other hand, seem to be intended for durable commemoration connected to a specific place. This is formulated in Gesta Danorum, written by the Dane Saxo Grammaticus at the beginning of the thirteenth century, where he admits that the historiography of his fellow countrymen is deficient, since the

23 The Poetic Edda 2014, 194; Guðrúnarkviða onnur 21-24: 21 Fœrði mér Grímildr / full at drecca, / svalt ok sárlict, / né ec sacar munðac: / pat var um aukit / urðar magni, / sva[l]koldom sæ / oc son<ar> dreyra 22 Vóro í horni / hvers kyns stafir / ristnir ok roðnir / -ráða ec ne máttac-, / lyngfiscr langr, / lanz Haddingia / ax óscorit, / innleið dýra.

24 Alfræði íslenzk 1917-1918, vol. 3, 88. 
Latin language-a prerequisite for a literature fit to preserve the history of his own people!-only recently came to his land. However, the lack of Latin script does not mean that his fellow countrymen had no written tradition of commemoration at all, since the great deeds of their heroes were not only praised in poems,

Nec ignotum uolo Danorum antiquiores conspicuis fortitudinis operibus editis glorie emulatione suffusos Romani stili imitatione non solum rerum a se magnifice gestarum titulos exquisito contextus genere ueluti poetico quodam opere perstrinxisse, uerum etiam maiorum acta patrii sermonis carminibus uulgata lingue sue literis saxis ac rupibus insculpenda curasse. Quorum uestigiis ceu quibusdam antiquitatis uoluminibus inherens tenoremque ueris translationis passibus emulatus metra metris reddenda curaui, quibus scribendorum series subnixa non tam recenter conflata quam antiquitus edita cognoscatur, quia presens opus non nugacem sermonis luculentiam, sed fidelem uetustatis notitiam pollicetur. Quantum porro ingenii illius homines historiarum edituros putemus, si scribendi sitim Latinitatis peritia pauissent, quibus tam etsi Romane uocis notitia abesset, tanta tradende rerum suarum memorie cupido incessit, ut uoluminum loco uastas moles amplecterentur, codicum usum a cautibus mutuantes? (praefatio 1,3)

I should like it to be known that Danes of an older age, filled with a desire to echo the glory when notable braveries had been performed, alluded in the Roman manner to the splendour of their nobly wrought achievements with choice compositions of a poetical nature; not only that, but they saw that the letters of their own language were engraved on rocks and stones to retell those feats of their ancestors which had been made popular in the songs of their mother tongue. Adhering to the tracks of these verses, as if to some ancient volumes, and following the sense with the true steps of a translator, I have assiduously rendered one poem by another; my chronicle, relying on these aids, should be recognised not as something freshly compiled but as the utterance of antiquity; this book is thereby guaranteed to give a faithful understanding of the past, not a frivolous glitter of style. Moreover, how much historical writing might we suppose men of such genius would have published if they had slaked their thirst for composition knowing Latin? Even when they had no acquaintance with the Roman tongue, they were taken by such an urge to transmit their record to posterity that in absence of books they resorted to massive boulders and granite for their pages.

These inscriptions of heroic poetry in stones and rocks mentioned by Saxo indeed belong to the corpus of narrated inscriptions: the sources and poems to which he refers in this passage do not correspond to any extant inscriptions discovered thus far.

Similar to how Saxo envisions the outstanding deeds of prehistoric times to be literally engraved into the material landscape of Denmark itself, the Norwegian Óláfs páttr Geirstaðarálfs depicts the continuity of the Norwegian kingdom engraved into the Norwegian soil. ${ }^{25}$ According to the story, when Olaf's mother is in labour but unable to give birth, Hrani-one of the followers of Olaf's father Haraldr-has a dream in which the western Norwegian petty king Óláfr digrbeinn instructs him to open his

25 Óláfs páttr Geirstaðaálfs 1941, 726. The Óláfs páttr Geirstaðarálfs is part of the first part of Saga Óláfs konungs hins helga (The saga of King Olav the Saint). The discussed section originates from the manuscript Holm perg 1 fol (Bergsbók) from the early fifteenth century. 
grave mound, where runes in the earth will guide him to the grave of Óláfr. In it he will find several items, which will speed the queen's delivery if brought to her. The items are intended for her son who shall be named after the petty king Óláfr. The name and the items imbued with the presence of the deceased petty king are thus passed to the newborn child, making him his successor. Likewise, the continuity of the Norwegian kingdom, the path from one Olaf to the next, is engraved with the runes into the land itself.

Stone monuments acting to preserve the memory of eminent figures and tie this commemoration to a specific place also factor into a number of translated sagas (such as the grave of Achilles in Alexanders saga [15f.]) and hagiographic works. ${ }^{26}$ In this context, it is surprising that the historical custom of erecting rune stones for commemoration is hardly reflected in the literature. This may be due to the fact that many of these stones were erected in Sweden, whereas the "canonic" literature explored here originated from the western part of the Nordic region. A few rune stones from the Swedish and Danish areas from the Viking Age attest to a poetic tradition similar to the eddic and skaldic poetry passed down in manuscripts from western Scandinavia. ${ }^{27}$ Some Old Norse sources corroborate the custom that stones were erected to commemorate the deceased. The eddic poem Hávamál discussed above emphasises the importance of heirs for commemoration, since "seldom do memorial stones / stand by the wayside, / unless one kinsman raises them for another" (sialdan bautarsteinar / standa brauto nær, / nema reisi niðr at nið, stanza 72). But the reference does not specifically mention an inscription. The Ynglinga saga ascribes the introduction of the custom to erect stone monuments to Odin, but here, too, no mention of runes or inscriptions is made. ${ }^{28}$

Locostatic inscriptions do not only serve a commemoration bound to a particular place, but may also, at times, have a magical effect. This is the case with a further example from Egils saga (ch. 57), where Egill raises a níðstong on an isle off the coast of Norway facing towards a royal manor near the city of Bjørgvin (Bergen). He raises this mocking pole against the Norwegian King Eiríkr:

26 Such as for example the sarcophagus of St Stephanus (according to the Icelandic Homily Book from c. 1200 , fol. $\left.95 \mathrm{v}^{17-19}\right)$.

27 In Östergötland, on the rune stone from Rök from the ninth century, which features the most extensive (and still not conclusively interpreted) inscription of around 750 runes, a stanza in the eddic verse metre refers to a king named Theodoric (the Great?; Düwel 2001, 114-118); the stone from Karlevi from Öland (from around 1000) commemorates a Danish Viking leader (ibid., 134) in the most elegant and difficult skaldic verse metre dróttkvætt ("court tone").

28 See von See et al. 2019, 666-669. 
er peir váru seglbúnir, gekk Egill upp í eyna. Hann tók í họnd sér heslistọng ok gekk á bergsnǫs nǫkkura, pá er vissi til lands inn; pá tók hann hrosshofuð ok setti upp á stọngina. Sỉðan veitti hann formála ok mælti svá: "Hér set ek upp níðstǫng, ok sný ek pessu níði á họnd Eiríki konungi ok Gunnhildi dróttningu,"-hann sneri hrosshofðinu inn á land,-“sný ek pessu níði á landvættir pær, er land petta byggva, svá at allar fari pær villar vega, engi hendi né hitti sitt inni, fyrr en pær reka Eirík konung ok Gunnhildi ór landi.” Siððan skýtr hann stǫnginni niðr í bjargrifu ok lét par standa; hann sneri ok hofðinu inn á land, en hann reist rúnar á stonginni, ok segja pær formála penna allan. (171)

When their sails were hoisted, Egill went back on to the island. He took a hazel pole in his hand and went to the edge of a rock facing inland. Then he took a horse's head and put it on the end of the pole. Afterwards he made an invocation, saying, "here I set up this scorn-pole and turn its scorn upon King Eirik and Queen Gunnhild"-then turned the horse's head to face land-“and I turn its scorn upon the nature's spirits that inhabit this land, sending them all astray so that none of them will find its resting-place by chance or design until they have driven King Eirik and Gunnhild from this land.” Then he thrust the pole into a cleft in the rock and left it to stand there. He turned the head towards the land and carved the whole invocation in runes on the pole.

With its face in the direction of the Norwegian mainland, the pole, it is suggested, banishes the prevailing land spirits. That is to say that the pole is able to cause this ban due to its position and orientation. It is worth remarking that this episode is one of the very few examples of narrated inscriptions where the very wording of a magical inscription is quoted in its entirety. The vast majority of the narrated inscriptions only mention the act of carving without relaying the actual content.

\section{Areas of Application}

To sum up the various applications of inscriptions in Old Norse texts: One can distinguish-though not always clearly-between the primary function of writing (to represent language), and secondary functions (where the main function is unrelated to the representation of a system of linguistic signs). The latter is the case when script is deployed as a form of magic, as in love charms, harmful spells or the magical expulsion of the royal couple in Egils saga. ${ }^{29}$ It also seems to be the background in Sigrdrifumál, where almost every object can be augmented with runes and, through them, made more effective. These inscriptions intensify the skills and properties inherent in the inscribed object. The carved runes impart a magical or mythic power which becomes effective through their presence in the material. This effect remains with the material even after the runic signs are destroyed when the surface is scraped off and stirred into the mead, as described in Sigrdrifumál 18. The magical use of script in particular is associated with heathen customs. This may be one of the reasons why such carvings are relayed in such dazzling detail, as we see with the log which causes

29 For such secondary functions of script, see Geier 1994. 
Grettir's death. In some magical rituals, however, the material inscription must be supplemented with an oral recitation for the charm to be effective, as is the case with Egill's níðstong.

Where writing is applied in its primary function, the representation of language, it frequently serves to bridge a distance in time or space and thus also separates sender and receiver in terms of narrative structure. ${ }^{30}$ Of course, such a message may be unreliable and may no longer represent the intention of the sender, as we have seen with Gudrun's message to her brothers in Atlamál: the warning is manipulated into an invitation, and thus brings about the brothers' doom. Since this counterfeit is in fact visible to an expert eye-the eddic poem highlights the vital necessity of a thorough exegesis-it provides an example of textual criticism ante verbum. Unlike mobile messages, inscriptions commemorating a person or an event are generally bound to one place. Memory belongs to a land, such as the Danish heroic stories which Saxo claims to have taken from rock inscriptions in his Gesta Danorum, or is tied to a funerary monument which commemorates the dead.

Narrated inscriptions where stanzas carved in pieces of wood or tablets claim to serve as a written record of poetry merit additional consideration. One prominent example appears, once again, in Egils saga. The saga describes how Egill overcomes his great sorrow for the loss of his two sons by composing the skaldic poem Sonatorrek (Irreparable Loss of Sons), one of the finest and most well-known skaldic poems of the Nordic Middle Ages, consisting of 24 to 25 stanzas. His daughter Porgerðr who encourages him to compose the poem simultaneously carves the whole skaldic poem onto a piece of wood. ${ }^{31}$ This appears implausible-due to the time such a carving would take, the many pieces of wood she would need for the carving, and finally because no such long poem is known to have been transmitted on such a medium. ${ }^{32}$ Nevertheless, several sagas describe lengthy inscriptions carved into wooden logs. Qrvar-Odds saga from the thirteenth century describes how the saga hero Qrvar-Oddr (Arrow-Oddr) composes an Evikviða, a poem that reviews his life. He urges his companions who sit next to him "to carve in accordance with the poem that I intend to compose about my actions and my life [...] and they carve into a piece of wood"; ${ }^{33}$ depending on the manuscript, this poem comprises up to 71 four-lined stanzas (ibid., 198-208). We may

30 For this aspect, see Ehlich 1994.

31 Egils saga 1933, ch. 78, 242-267.

32 Nonetheless, several scholars assume that such a transmission was plausible for an audience of the thirteenth century; see for example Holm 1975.

33 "rísta eptir kvæði pví er ek vil yrkja um athafnir mínar ok ævi [...] en peir rísta eptir á speldi”; Qrvar-Odds saga 1888, 195; this passage is preceded by a drinking competition with accompanying quarrels, during which a number of stanzas are recited and carved into a board by the princess and her advisor, see ibid. 169. In ch. 62 of Grettis saga, an Ævikviða of a giant is mentioned which is carved by his daughter into a wooden log (Grettis saga 1936, 203). 
assume that the poetical inscription mentioned either corresponds to the quoted text or was expected to be commonly known. ${ }^{34}$

A narrated inscription may be considered a more trustworthy witness to the authenticity of a poem or stanza than mere oral tradition or it may highlight the content as worthy to be passed on word for word. The poems attributed to Egill and QrvarOddr are carved onto objects which have no other purpose than to preserve the poems. Quite the opposite applies to a stanza in chapter 24 of Flóamanna saga, that is inscribed onto a paddle and which may be reminiscent of a work song: ${ }^{35}$

\author{
Vaskat ek dási, \\ er ek pessa dró \\ opt ósjaldan \\ ár á borði; \\ sjá gerði mér \\ sára lófa, \\ meðan heimdragi \\ hnauðat rauða.
}

\author{
I was no laggard \\ When I pulled this oar \\ Again and again, \\ At the ship's side; \\ It gave me \\ sore palms \\ while the stay-at-home \\ beat at bog-ore.
}

The condition and location of the script-bearing object effectively underline the content of the stanza: the paddle is found in fragmented form by the shipwrecked protagonists in the Greenlandic ice, highlighting the dangerous life of Icelandic seafarers. This last example reminds us of how the materiality of an inscription imbues an inscribed artefact with additional semantic content which goes beyond what the abstract sign system of script expresses in language. The inscribed paddle performs its own story of the shipwreck and the onerous existence of seafarers, recalling Odin's ordeal in Hávamál and suggesting that for both mortal and god the boon of material writing is indelibly bound up with the struggle to survive and thrive in the North.

\section{Works Cited}

\section{Primary Sources}

Alexanders saga. Islandsk oversættelse ved Brandr Jónsson (1925), ed. by Finnur Jónsson, Copenhagen.

Alfræði íslenzk. Islandsk encyklopædisk litteratur (1917-1918), vol. 3, ed. by Kr. Kålund (STUAGNL 45), Copenhagen.

Codex Frisianus. En Samling af norske Konge-Sagaer (1871), ed. by C. R. Unger, Kristiania.

\footnotetext{
34 The majority of manuscripts of Egils saga transmit only the first stanzas of Sonatorrek; only one redaction in two transcripts from the seventeenth century features the whole text (Egils saga 1933). 35 For this, see Perkins 1969.
} 
Edda. Die Lieder des Codex regius nebst verwandten Denkmälern (19624), vol. I: Text, first ed. by

Gustav Neckel, fourth ed. by. Hans Kuhn, Heidelberg.

Egil's Saga (2000), in: The Sagas of Icelanders. A Selection, trans. by Bernard Scudder, New York et al., 3-184.

Egils saga Skalla-Grímssonar (1933), ed. by Sigurður Nordal (Íslenzk Fornrit 2), Reykjavík.

First Grammatical Treatise. The Earliest Germanic Phonology (1974), trans., ed. and with a commentary by Einar Haugen (Language monographs 25), Millwood, NY.

Flóamanna saga (1992), in: Harðar saga, ed. by Pórhallur Vilmundarson and Bjarni Vilhjálmsson (Íslenzk Fornrit 13), Reykjavík, 229-327.

Grettis saga Ásmundarsonar (1936), ed. by Guðni Jónsson (Íslenzk Fornrit 7), Reykjavík.

The Icelandic Homily Book. Perg. $154^{\circ}$ in the Royal Library 1993, Stockholm, İ quarto 3, ed. and facs. by Andrea de Leeuw van Weenen, Reykjavík.

Magus saga jarls (1884), in: Fornsögur Suðrlanda: Magus saga jarls, Konraðs saga, Bærings saga, Flovents saga, Bevers saga, ed. by Gustaf Cederschiöld, Lund, 1-42.

Nítída saga (1965), in: Late Medieval Icelandic Romances, vol.5, ed. by Agnethe Loth, trans. by J. B. Dodsworth, (Editiones Arnamagneanae B 24), Copenhagen.

Óláfs páttr Geirstaðarálfs (1941), in: Saga Óláfs konungs hins helga. Den store saga om Olav den hellige efter pergamenthåndskrift i Kungliga Biblioteket i Stockholm nr. 2 4to [...] (1-2), vol. 2, Oslo, 715-735.

Qrvar-Odds saga (1888), ed. by Richard Constant Boer, Leiden.

The Poetic Edda (2014), trans. by Carolyne Larrington, Oxford.

Rognvaldr jarl Kali Kolsson, Lausavísur 1 (2009), ed. by Judith Jesch, in: Kari Ellen Gade (ed.), Poetry from the Kings' Sagas, vol. 2: From c. 1035 to c. 1300 (Skaldic Poetry of the Scandinavian Middle Ages 2), Turnhout, 576-577.

The Saga of Grettir (2004), in: Three Icelandic Outlaw Sagas, ed. and trans. by Anthony Faulkes, London, 69-263.

The saga of the Volsungs: the Norse epic of Sigurd the dragon slayer (1990), introd. and trans. by Jesse L. Byock, Berkeley et al.

Saxo Grammaticus (2015), Gesta Danorum. The History of the Danes, vol. 2, ed. by Karsten Friis-Jensen, trans. by Peter Fisher, Oxford.

Snorri Sturluson (1911), Heimskringla, ed. by Finnur Jónsson, Copenhagen.

Snorri Sturluson (2011), Heimskringla, vol.1: The Beginnings to Óláfr Tryggvason, trans. by Alison Finlay and Anthony Faulkes, London.

Den tredje og fiærde grammatiske afhandling i Snorres Edda tilligemed de grammatiske afhandlingers prolog og to andre tillæg (1884), ed. by Björn Magnússon (Islands grammatiske litteratur i middelalderen 2/STUAGNL 12), Copenhagen.

Vọlsunga saga ok Ragnars saga loðbrókar (1906-1908), ed. by Magnus Olsen (STUAGNL 36), Copenhagen.

\section{Secondary Sources}

Dillmann, François-Xavier (2003), “Runenmeister”, in: Reallexikon der Germanischen Altertumskunde, vol. 25, Berlin/New York, 537-546.

Düwel, Klaus (20014), Runenkunde, Stuttgart et al.

Ebel, Else (1964), Die Terminologie der Runentechnik, Göttingen (Phil. Diss.). 
Ehlich, Konrad (1994), “Funktion und Struktur schriftlicher Kommunikation”, in: Hartmut Günter/ Otto Ludwig (eds.), Schrift und Schriftlichkeit / Writing and its Use. Ein interdisziplinäres Handbuch internationaler Forschung / An Interdisciplinary Handbook of International Research, Berlin et al., 18-41.

Geier, Manfred (1994), "Sekundäre Funktionen der Schrift”, in: Hartmut Günther and Otto Ludwig (eds.), Schrift und Schriftlichkeit / Writing and its Use. Ein interdisziplinäres Handbuch internationaler Forschung / An Interdisciplinary Handbook of International Research, Berlin et al., 678-686.

Glauser, Jürg (2006), “Mittelalter”, in: Ibid. (ed.), Skandinavische Literaturgeschichte, Stuttgart/ Weimar, 1-50.

Holm, Gösta (1975), “Litteratur i runskrift och ett västgötskt ortnamn”, in: Nordiske Studier. Festskrift til Chr. Wetergård-Nielsen, Copenhagen, 103-119.

Hornbacher, Annette/Frese, Tobias/Willer, Laura (2015), “Präsenz”, in: Thomas Meier/Michael R.

Ott/Rebecca Sauer (eds.), Materiale Textkulturen. Konzepte - Materialien - Praktiken (Materiale Textkulturen 1), Berlin et al., 87-99.

Ordbog over det norrøne prosasprog / A Dictionary of Old Norse Prose, Ordliste (basis): <http://onp. ku.dk> [ONP online] (last accessed: 30.05.2019).

Perkins, Richard (1969), “A Medieval Icelandic Rowing Chant”, in: Medieval Scandinavia 2, 92-101. von See, Klaus/La Farge, Beatrice/Schulz, Katja/Picard, Eve/Priebe, Ilona/Gerhold, Wolfgang/ Dusse, Debora/Teichert, Matthias/Horst, Simone (1997-2019), Kommentar zu den Liedern der Edda, vol.1 (2019): Götterlieder. Vọluspá, Hávamál, Vafprúðnismál, Grímnismál; vol. 2 (1997): Götterlieder. Skírnismál, Hárbarðsliód, Hymiskviða, Lokasenna, Prymskviða; vol. 3 (2000): Götterlieder. Vọlundarkviða, Alvíssmál, Baldrs draumar, Rígspula, Hyndlolioð, Grottasọngr; vol. 5 (2006): Heldenlieder. Frá dauða Sinfiọtla, Grípisspá, Reginsmál, Fáfnismál, Sigrdrífumál, Heidelberg.

Seim, Karin Fjellhammer (2004), “Runologie”, in: Odd Einar Haugen (ed.), Handbok i norrøn filologi, Bergen, 119-174. 
